University of Nebraska - Lincoln

DigitalCommons@University of Nebraska - Lincoln

Publications, Agencies and Staff of the U.S.

Department of Commerce

U.S. Department of Commerce

$10-2008$

\title{
North Pacific Right Whale (Eubalaena japonica) Seasonal and Diel Calling Patterns from Long-Term Acoustic Recordings in the Southeastern Bering Sea, 2000-2006
}

\author{
Lisa Munger \\ Scripps Institution of Oceanography, University of California, San Diego \\ Sean Wiggins \\ Scripps Institution of Oceanography, University of California, San Diego \\ Sue Moore \\ NOAA, Alaska Fisheries Science Center \\ John Hildebrand \\ University of California, San Diego, 9500 Gilman Drive, mail code 0205, La Jolla, California
}

Follow this and additional works at: https://digitalcommons.unl.edu/usdeptcommercepub

Part of the Environmental Sciences Commons

\footnotetext{
Munger, Lisa; Wiggins, Sean; Moore, Sue; and Hildebrand, John, "North Pacific Right Whale (Eubalaena japonica) Seasonal and Diel Calling Patterns from Long-Term Acoustic Recordings in the Southeastern Bering Sea, 2000-2006" (2008). Publications, Agencies and Staff of the U.S. Department of Commerce. 27.

https://digitalcommons.unl.edu/usdeptcommercepub/27

This Article is brought to you for free and open access by the U.S. Department of Commerce at DigitalCommons@University of Nebraska - Lincoln. It has been accepted for inclusion in Publications, Agencies and Staff of the U.S. Department of Commerce by an authorized administrator of DigitalCommons@University of Nebraska - Lincoln.
} 


\title{
North Pacific right whale (Eubalaena japonica) seasonal and diel calling patterns from long-term acoustic recordings in the southeastern Bering Sea, 2000-2006
}

\author{
LISA M. MUNGER \\ SEAN M. WigGINS \\ Scripps Institution of Oceanography, \\ University of California, San Diego, \\ 9500 Gilman Drive, mail code 0205, \\ La Jolla, California 92093-0205, U.S.A. \\ E-mail: lmunger@ucsd.edu

\section{SuE E. MOORE} \\ NOAA, Alaska Fisheries Science Center, \\ 7600 Sand Point Way NE, Seattle, \\ Washington 98115 , U.S.A.

\section{JOHN A. HILDEBRAND} \\ Scripps Institution of Oceanography, \\ University of California, San Diego, \\ 9500 Gilman Drive, mail code 0205, \\ La Jolla, California 92093-0205, U.S.A.
}

\begin{abstract}
We assessed North Pacific right whale (Eubalaena japonica) seasonal and daily calling patterns in the southeastern Bering Sea (SEBS) using long-term hydrophone recordings from October 2000 through January 2006. We detected right whale calls on the SEBS middle shelf ( $<100 \mathrm{~m}$ depth) as early as May, intermittently throughout summer and fall, and as late as December. Calls also were detected on one day in June 2005 on the SEBS slope $(>1,000 \mathrm{~m})$, but were not detected near Kodiak Island from April to August 2003. In months with calls, detections occurred on more days in July-October $(\geq 6 \mathrm{~d} / \mathrm{mo})$, than from May to June or November to December $(\leq 3 \mathrm{~d} / \mathrm{mo})$. Calls were clustered in time and were usually detected on 1-3 consecutive days with a median interval of $6.5 \mathrm{~d}$ for calls $>1 \mathrm{~d}$ apart. Hourly calling rates were significantly higher at night than during the day. These data indicate that right whales occur in the SEBS later in the year than previously known, intermittently pass through the middle-shelf study region, and usually remain there no longer than a few days. Right whale habitat use in the SEBS may intensify in mid-summer through early fall based on higher monthly and daily call detection rates.
\end{abstract}


Key words: North Pacific right whale, Eubalaena japonica, acoustic monitoring, Bering Sea.

North Pacific right whales (Eubalaena japonica) are among the world's most endangered large whale species due to intensive commercial whaling in the 19th century and further depletion by illegal whaling in the 1960s (Doroshenko 2000, Brownell et al. 2001, Scarff 2001). Nineteenth- and twentieth-century catch and sighting data suggest that at least two right whale populations exist in the North Pacific, one in the west and the other in the east (Brownell et al. 2001, Clapham et al. 2004). Abundance estimates for these populations are uncertain, but the western population probably consists of a few hundreds of individuals, whereas the eastern population is even smaller (Brownell et al. 2001). Currently in the eastern North Pacific, 23 individual right whales have been identified by photographs and biopsy samples (Wade et al. 2006), and sightings of at least three mother-calf pairs during surveys within the last decade provide hope that the population may be capable of recovery (LeDuc 2004, Wade et al. 2006). Little is known about the seasonal distribution of eastern North Pacific right whales, especially with regard to migration routes and wintering grounds (Brownell et al. 2001, LeDuc et al. 2001, Shelden et al. 2005).

Like other right whale species (Eubalaena sp.), eastern North Pacific right whales appear to migrate seasonally, with recent and historic sightings indicating a northward movement in spring to high-latitude summer feeding grounds, and a southward movement in fall (Townsend 1935, Brownell et al. 2001, Clapham et al. 2004, Shelden et al. 2005). Data from 1835 to 1852, the peak period of commercial whaling for North Pacific right whales, suggest that right whales occurred in the eastern Bering Sea as early as April and were abundant there by May (Scarff 1991). The southeastern Bering Sea (SEBS) and western Gulf of Alaska (GoA) historically supported high concentrations of right whales from June through September; the western GoA was known to whalers in the 19th century as the lucrative "Northwest Ground" or "Kodiak Ground." Small numbers of right whales have been seen in most summers since 1996 in the SEBS (Goddard and Rugh 1998, Moore et al. 2000, LeDuc et al. 2001, Tynan et al. 2001, LeDuc 2004, Barlow 2005, Wade et al. 2006), with occasional recent sightings in the western GoA (Waite et al. 2003). In a 2004 satellite telemetry study of two tagged North Pacific right whales, the whales traveled around the SEBS middle and outer shelf regions, but did not leave the Bering Sea during $40 \mathrm{~d}$ of monitoring in August-September (Wade et al. 2006). The latest reported right whale sighting of the year in the SEBS was in October 1999 (Brownell et al. 2001). Sightings of North Pacific right whales are rare in winter, both historically and recently. Winter sightings in the eastern North Pacific have been geographically scattered and are usually single animals (Brownell et al. 2001).

Most of our current knowledge of eastern North Pacific right whales is based on visual surveys, which are conducted primarily in summer months in the Bering Sea and Gulf of Alaska and when weather and light conditions are favorable for vessels and aircraft. During the 19th and 20th centuries, the majority of right whale sightings in the Bering Sea were in June through September, the months with highest search effort (Scarff 1991, Brownell et al. 2001, Shelden et al. 2005); right whale surveys and sightings since 2000 have also been only in summer months (e.g., LeDuc et al. 2001, LeDuc 2004, Barlow 2005, Wade et al. 2006). Recently designated critical habitat areas in the SEBS and western GoA are based on visual sightings of 
right whales since 1970 (Federal Register 2006). Traditional cetacean visual surveys provide photographic, genetic, and observational data, but are constrained to operate in good weather and daylight, and are usually limited to a few to several weeks in duration due to vessel, aircraft, and personnel expense and schedules. Because of these constraints in visual sighting data, it is unclear whether right whales are consistently present in the SEBS throughout the summer, and whether they are present at other times of year. As a complementary tool to visual surveys, long-term, passive acoustic recorders can operate continuously for months to years, through poor weather and darkness, and thus are useful for monitoring the seasonal distribution and diel calling behavior of calling cetaceans (e.g., Thompson and Friedl 1982; Clark et al. 1996; Stafford et al. 2001, 2005; Mellinger et al. 2004a, b, 2007; Širović et al. 2004; Moore et al. 2006; Oleson et al. 2007; Wiggins et al. 2005).

We present results from the first long-term acoustic monitoring study of critically endangered North Pacific right whales (hereafter referred to as "right whales") in the southeast Bering Sea. The use of autonomous acoustic moorings allowed us to conduct almost year-round monitoring at several geographic locations, thereby obtaining data on temporal and spatial distribution of right whales that visual surveys alone could not provide. We deployed moored hydrophones that recorded for months-long periods between October 2000 and January 2006 at nine sites in the SEBS ranging from $70 \mathrm{~m}$ to $1,880 \mathrm{~m}$ in depth, and one site in the western GoA $(800 \mathrm{~m})$. Right whale call detections in the SEBS exhibit seasonal and diel patterns, and right whales were acoustically detected at times of year and locations where they have not been seen for several decades.

\section{METHODS}

We analyzed data from seafloor-moored, long-term, acoustic recording packages (ARPs) (Wiggins 2003, Wiggins and Hildebrand 2007) deployed at six locations in the SEBS middle-shelf region $(\sim 70 \mathrm{~m})$, three locations along the SEBS outer shelf and slope $(125 \mathrm{~m}$ and $>1,500 \mathrm{~m})$, and one site southeast of Kodiak Island in the western GoA $(800 \mathrm{~m})$ (Fig. 1). Mooring site names, locations, recording dates, sampling rates, and number of call detections are summarized in Table 1. We resampled high-frequency $(>1 \mathrm{kHz}$ ) recordings to a sampling rate of $1 \mathrm{kHz}$ prior to further processing, using the "decimate" function in the Matlab Signal Processing Toolbox v 6.2, which applies an eighth order lowpass Chebyshev type I forward and backward filter (IEEE 1979).

Right whale calls in the Bering Sea were first recorded in 1999 using directional frequency analysis and recording (DIFAR) sonobuoys deployed from a ship (McDonald and Moore 2002). During the 1999 survey and subsequent surveys in 2002 and 2004, DIFAR sonobuoys were used to localize calls from right whales that were confirmed by visual sightings (McDonald and Moore 2002, Wade et al. 2006). Over $80 \%$ of right whale calls recorded during these surveys were frequency-modulated "up-calls" with variable frequency and sweep rate characteristics on average from 90-150 Hz and about $0.7 \mathrm{~s}$ in duration (e.g., McDonald and Moore 2002). "Down-up calls" accounted for $5 \%$ of the calls sampled and swept down for 10-20 Hz before becoming a typical "up-call." Other call types, such as downsweeps and constant-tonal "moans," accounted for $<10 \%$ of total calls and were usually interspersed with up-calls. We therefore used up-calls and down-up calls with a prominent upsweep to indicate right whale presence in this study (Fig. 2). The frequency upsweep portion of right 


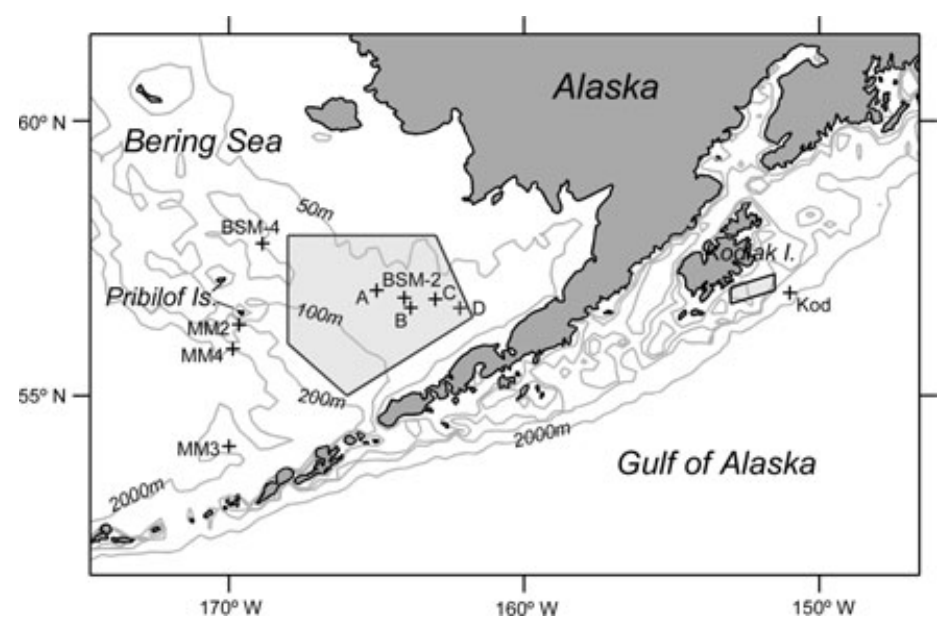

Figure 1. Map of study area. Depth contours shown are $50 \mathrm{~m}, 100 \mathrm{~m}, 200 \mathrm{~m}$, and 2,000 m (bathymetry data from Smith and Sandwell 1997). “+” symbols represent ARP deployments, 2000-2006 (see Table 1). Shaded polygons are federally designated right whale critical habitat, enclosing 182 of 184 SEBS right whale sightings and 5 of 14 GoA right whale sightings since 1970 (Federal Register 2006).

whale calls is an important classification criterion for North Atlantic right whales (Eubalaena glacialis) as well (Gillespie 2004, Matthews 2004).

We detected potential right whale up-calls in long-term recordings using two methods. The first was to compute "long-term spectral averages" (LTSAs) of acoustic recordings by computing fast fourier transforms (FFTs) and then averaging successive FFTs into a single spectral average and displaying successive spectral averages as spectrograms (Wiggins and Hildebrand 2007). To compute the FFTs we applied a Hanning window, $0 \%$ overlap, and $1-\mathrm{Hz}$ frequency bins (for FFT length of $0.5 \mathrm{~s}$ and $1 \mathrm{~s}$ for data sampled at $500 \mathrm{~Hz}$ and $1,000 \mathrm{~Hz}$, respectively); successive FFTs were averaged over $120 \mathrm{~s}$. Displaying data in the LTSA format allowed the analyst (L. Munger) to quickly visually scan through years of recordings, note times of potential right whale calling, and easily open the detailed data files for additional evaluation of calls. The second technique used for call detection was automatic spectrogram correlation using the software program Ishmael (Mellinger 2001). We cross-correlated spectrogram data from the acoustic recorders with a synthetic spectrogram kernel based on the North Pacific right whale up-call (Munger et al. 2005). Automatic detections were saved as individual sound files.

All data were processed using both of the above techniques, and potential right whale calls were reviewed using Triton, a Matlab-based acoustic data display and analysis software program (Wiggins 2003) or using Ishmael. We analyzed positive call detections aurally and visually using short-duration (seconds to minutes), higherresolution spectrograms (e.g., Figs. 2 and 3) to identify right whale calls and searched for additional calls by browsing short-duration spectrograms for at least one day before and one day after call detection times. Data were scanned until no calls were found for $24 \mathrm{~h}$.

Potential right whale calls were analyzed to distinguish them from calls made by other large baleen whale species common in the SEBS, including fin whales 


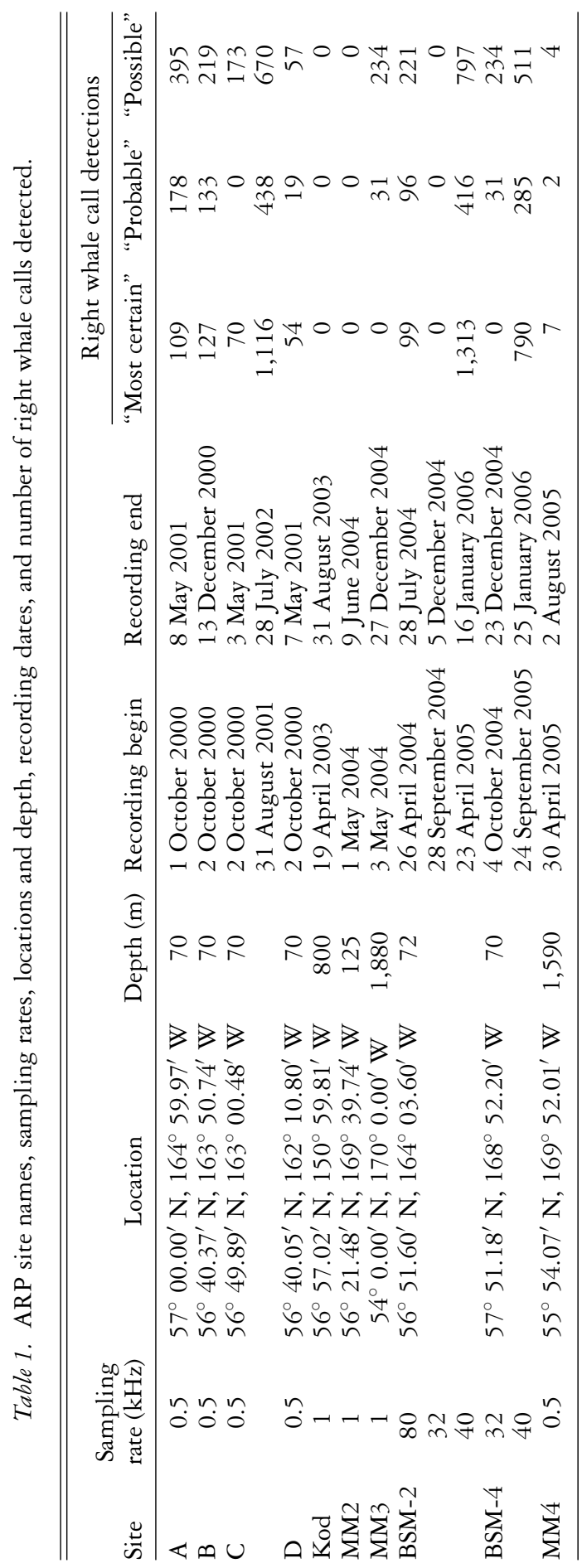



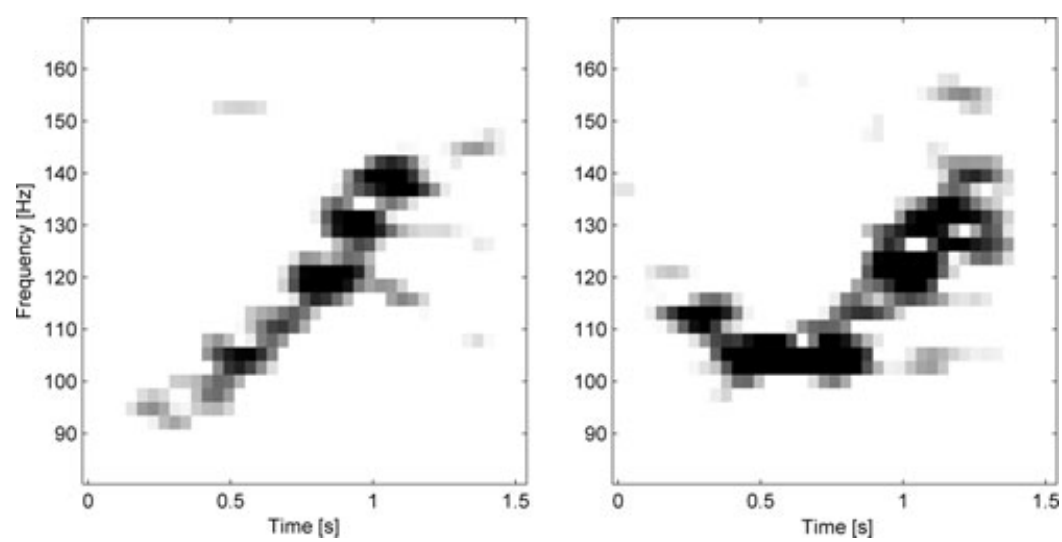

Figure 2. Spectrograms of right whale up-call (left) and down-up call (right). Sampling rate $=500 \mathrm{~Hz}, 200$-point FFT and same length Hanning window for $0.4 \mathrm{~s}$ window length and $3.4 \mathrm{~Hz}$ filter main lobe width ( $-3 \mathrm{~dB}$ from peak), $90 \%$ overlap.

(Balaenoptera physalus) and humpback whales (Megaptera novaeangliae), which also produce calls below $250 \mathrm{~Hz}$. Fin whale calls were easily distinguished from right whale calls because they are stereotyped, short $(<1$ s) downsweeps with most of the call frequency bandwidth below $50 \mathrm{~Hz}$ (e.g., Watkins et al. 1987, Thompson et al. 1992, McDonald et al. 1995). Humpback whale calls were more similar in appearance to right whale calls (Fig. 3); the main differences used to distinguish the two species are in their frequency range and temporal patterns. Most North Pacific right whale calls (Fig. 3A) are less than $250 \mathrm{~Hz}$ and are produced at irregular intervals usually greater than 5-10 s (McDonald and Moore 2002), and, like those of North Atlantic right whales, occur in bouts lasting several minutes with variable silent intervals up to several hours in length (Matthews et al. 2001, Vanderlaan et al. 2003). In comparison, humpback whale calls are generally more variable than right whale calls, ranging in frequency from $\sim 50 \mathrm{~Hz}$ to several $\mathrm{kHz}$ and often occurring less than $10 \mathrm{~s}$ apart (Fig. 3B). Humpback whales also produce songs that are characterized by consistent "phrases" repeated over long (minutes to hours) periods (Payne and McVay 1971). Humpback singing has been reported primarily in low-latitude winter breeding grounds, but has also been recorded on higher-latitude summer feeding grounds (Mattila et al. 1987, McSweeney et al. 1989, Clark and Clapham 2004). In the Bering Sea, we recorded humpback whale song fragments containing frequencies $<250 \mathrm{~Hz}$ (Fig. 3B), which appear similar to low-frequency components of humpback whale songs in other areas in the North Pacific (e.g., Cerchio et al. 2001, Fristrup et al. 2003).

Potential right whale call times (Coordinated Universal Time, UTC) were picked by cursor in a spectrogram display to within $\pm 0.5 \mathrm{~s}$ and each call was rated "most certain," "probable," or "possible," in order of decreasing certainty that the call was made by a right whale. "Most certain" right whale calls were up- or down-up calls similar to those recorded in the presence of right whales during prior surveys (e.g., McDonald and Moore 2002, LeDuc 2004, Barlow 2005, Wade et al. 2006, L. Munger, unpublished data) and had a relatively high signal-to-noise ratio (SNR). "Probable" right whale calls were either non-upswept right whale call types cooccurring with up-calls, or were more difficult to identify due to lower SNR or 


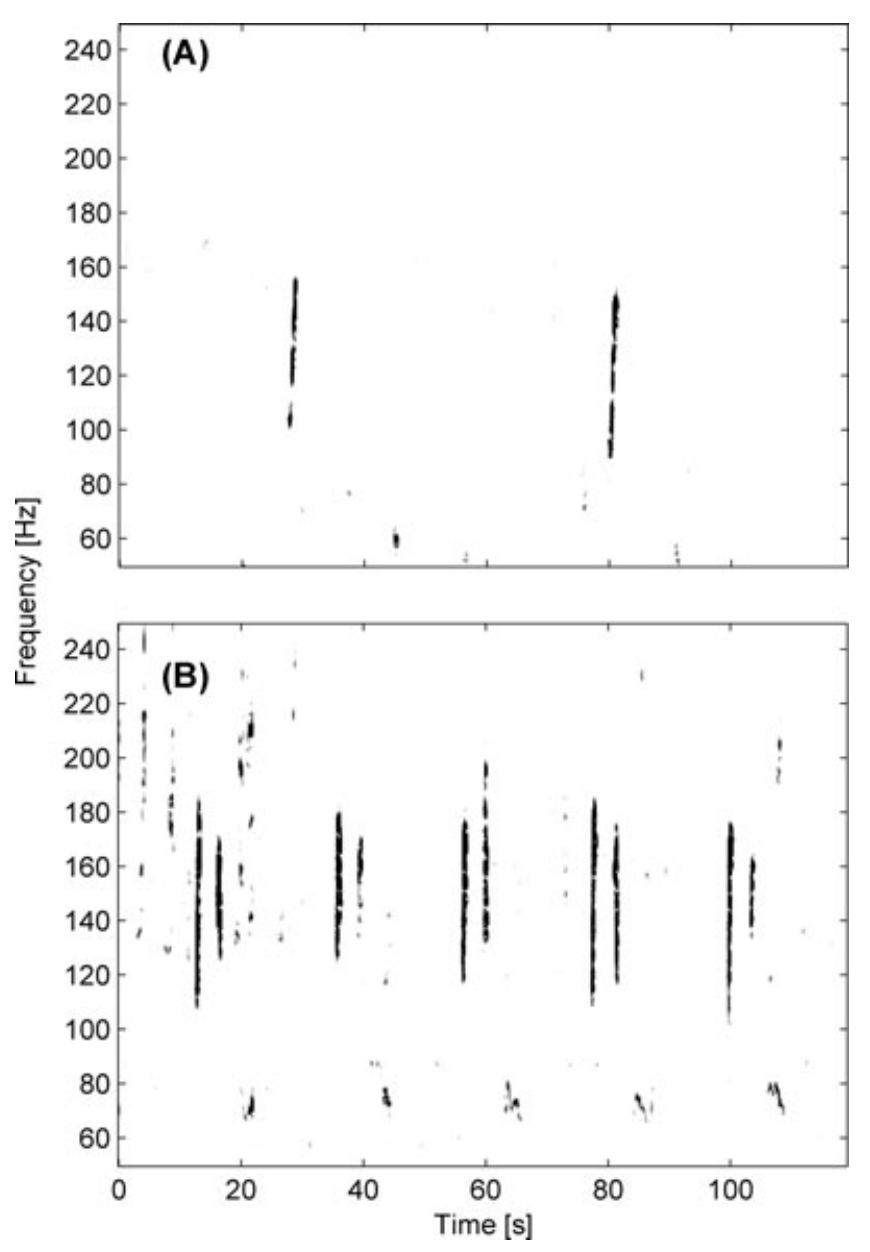

Figure 3. (A) Right whale "up" calls recorded by ARP at site C, August 2001. Spectrogram generated using Hanning window, FFT and frame size $=600$ points, $90 \%$ overlap, main lobe width $(-3 \mathrm{~dB})=1.2 \mathrm{~Hz}$. Original sampling rate $=500 \mathrm{~Hz}$. (B) Humpback song components recorded by ARP at site "B," October 2000. Same sampling rate and spectrogram parameters as $(\mathrm{A})$.

nearby detections of humpback whale calls. "Possible" right whale calls may have resembled right whale calls or portions of right whale calls, but were either too difficult to distinguish from humpback whale calls or had low SNR such that the analyst was not confident of the calling species. We did not include "probable" and "possible" right whale calls (19\% and 38\% of total detections; Table 1) in the results presented in this paper. Therefore the total numbers of actual right whale calls are probably underestimated, but seasonal and diel patterns were not affected by excluding lower-rated calls as they were interspersed with "most certain" calls.

Using cursor-picked call times, we calculated inter-call intervals for "most certain" calls during the longest continuous ARP recording at a single site (site C, 31 August 
2001-28 July 2002). We also analyzed diel patterns in right whale calling using combined SEBS middle-shelf recordings from all years. For each day with calls, we obtained the UTC of sunrise, sun transit (maximum altitude of sun relative to horizon), sunset, and start and end of nautical twilight $\left(-12^{\circ}\right.$ sun altitude relative to horizon) at the ARP site using data from the U.S. Naval Observatory website (http://aa.usno.navy.mil). Calls were categorized as occurring during "dawn" (sun altitude between $-12^{\circ}$ and $0^{\circ}$ prior to sunrise), "morning" (sun altitude increasing from $0^{\circ}$ to transit), "afternoon" (sun altitude decreasing from transit to $\left.0^{\circ}\right)$, "dusk" $\left(0^{\circ}\right.$ to $-12^{\circ}$ following sunset), and "dark" (sun below $-12^{\circ}$ to horizon). We computed hourly calling rates within each of these diel periods and subtracted the overall calling rate (calls/hour) for that 24-h day to obtain a mean-adjusted calling rate, in order to correct for variation in the total number of calls detected each day. We used a KruskalWallis test (Zar 1999) to rank and compare mean-adjusted calling rates across diel periods, and a Tukey-Kramer multiple comparison test to determine which, if any of the diel periods showed significant difference in mean rank of mean-adjusted right whale calling rates.

\section{RESULTS}

A total of 3,685 "most certain" right whale calls were detected, primarily on ARPs deployed on the SEBS middle shelf at $\sim 70 \mathrm{~m}$ depth (Table 1). Only seven "most certain" right whale calls were detected on the SEBS slope, at site MM4 (1,590 m depth) south of the Pribilof Islands on 14 June 2005. These calls were reviewed using a variety of spectrogram parameters and the surrounding data were thoroughly scanned. No humpback whale calls were detected in the $2 \mathrm{~d}$ surrounding the calls and although the SNR of these calls was somewhat low, the frequency sweep characteristics (upsweep of at least $20 \mathrm{~Hz}$ ) and call intervals (10 s to several minutes) were characteristic of right whale up-calls. No right whale calls of any quality rating were detected on two other SEBS outer shelf/slope ARPs (MM2, $125 \mathrm{~m}$ and MM3, $1,880 \mathrm{~m}$ ) in May-December 2004 or off Kodiak Island $(800 \mathrm{~m})$ in April-August 2003 (Table 1).

The number of right whale calls per day and recording effort are shown for the SEBS middle-shelf ARPs in Figure 4. The overall seasonal occurrence of right whale calls is shown in Figure 4(A), with calls per day plotted from the ARP with the maximum calling rate for that day across recording years. The earliest SEBS middleshelf right whale calls of any year were detected on 23 May 2004, and the latest right whale calls of any year were detected on 15 December 2005 (Fig. 4B). The highest daily calling rates ( $>300$ calls/d) were in August, September, and December.

Calls per day and recording effort for each year at SEBS middle-shelf sites are shown in Figure 4(B). In 2000 and early 2001, maximum calls/d are plotted for a single ARP to avoid duplicating counts of calls detected on more than one ARP. Effort in January 2006 at sites BSM-2 and BSM-4 is not shown; no right whale calls were detected during this time. The longest continuous deployments were August 2001-July 2002 (site C) and April 2005-January 2006 (site BSM-2); peak calling rates in these recordings occurred during August and September. Right whale calls were not detected in January through April in years with continuous $(2001,2002)$ or partial $(2004,2005,2006)$ effort during these months. Right whale calling was episodic throughout the season, with typical durations of one to three consecutive 

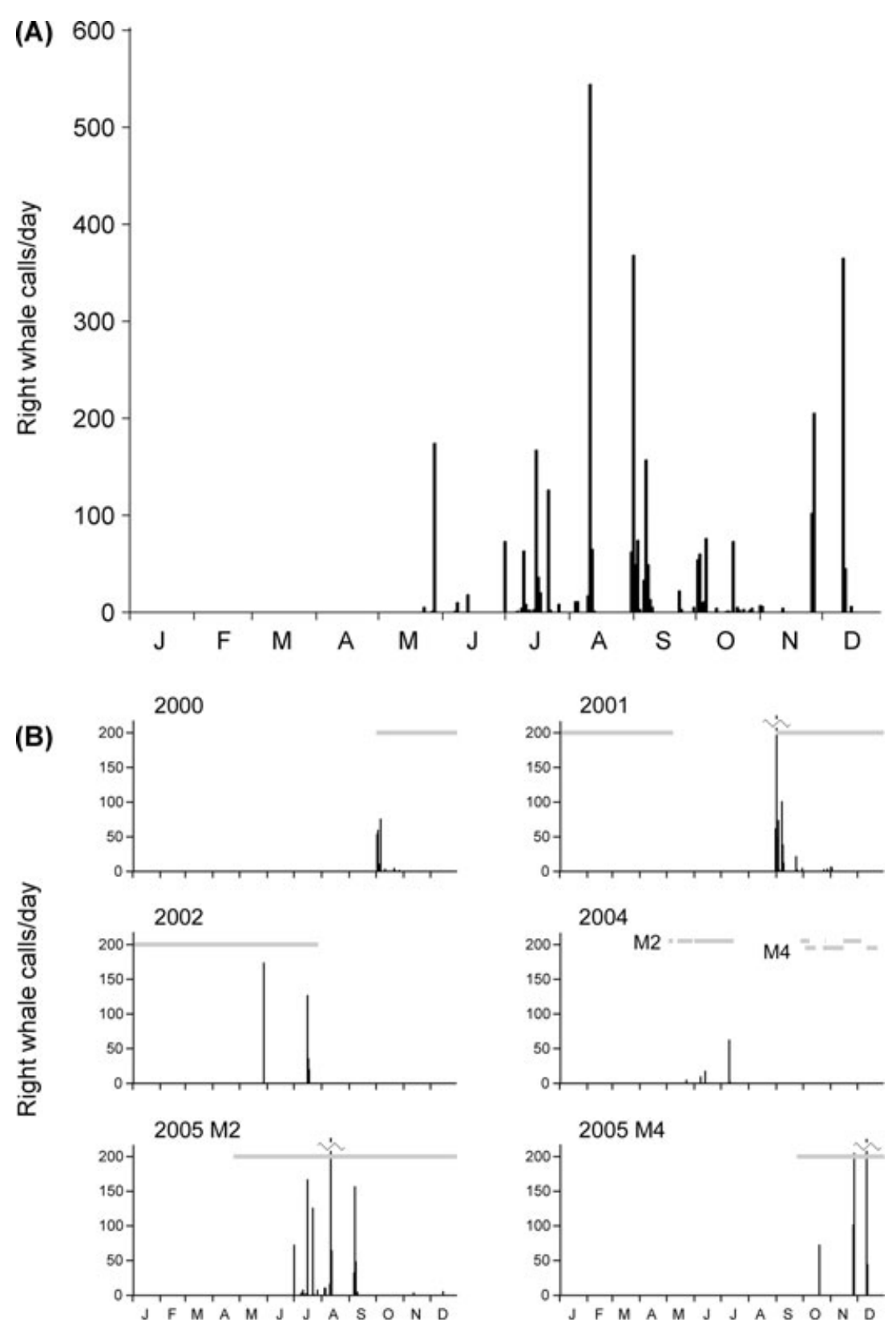

Figure 4. (A) Maximum number of "most certain" right whale calls/day among SEBS middle-shelf recording sites (ARP depth $<100 \mathrm{~m}$ ), 2000-2005. (B) calls/day for each year with recording effort; horizontal bars are recording duration; vertical bars are right whale calls/day (in 2000, data are calls/day from ARP with maximum calling rate on that day). Recording effort in January 2006 not shown; no calls detected in that month. 
days and up to $5 \mathrm{~d}$. The longest consecutive periods of right whale calling were in late summer and early fall. Intervals between days with calls ranged from 2 to $49 \mathrm{~d}$, with a median value of $6.5 \mathrm{~d}$.

The number of days per month (not necessarily consecutive) with right whale calls at each SEBS site is shown in Figure 5. Months with no call detections (January through April) are not shown. The months with the highest proportion of right whale calling days were July through October, with up to 11 calling days per month. The months with fewest right whale calling days (excluding months with zero detections) were May, June, November, and December; calls were detected on no more than $3 \mathrm{~d}$ during these months. Right whale calls were detected on at least one day per month in October through December 2005 at site BSM-4, and on one day in June 2005 at site MM4 on the SEBS slope south of the Pribilof Islands (see Fig. 1 for site labels).

Right whale calls were clustered in time over several scales (Fig. 6). Call intervals ranged from a few seconds to several months, with a median interval of $34 \mathrm{~s}(n=$ 1,116 calls). Over $80 \%$ of the calls were separated by $10 \mathrm{~s}$ to several minutes, with fewer than $10 \%$ of call intervals $<10 \mathrm{~s}$ apart or more than $\sim 17 \mathrm{~min}(1,000 \mathrm{~s})$ apart, respectively. Most of the calls greater than $17 \mathrm{~min}$ apart occurred within about a day of a previous call. A small number of calls $(<1 \%$ of total) were separated by weeks to months.

Mean-adjusted right whale calling rates on the SEBS middle shelf showed significant diel variation (Fig. 7; Kruskal-Wallis test; chi-square $=23.85$, df $=4, P<$ 0.01). Sample size was 68 for each diel period except for darkness $(n=51)$, due to the occurrence of some days with calls in mid-summer that never became completely dark at night (sun angle never below $-12^{\circ}$ ). Median mean-adjusted calling rates for dawn, morning, afternoon, dusk, and dark periods were $-0.208,-0.167,-0.188$, -0.167 , and 0.147 calls/h, respectively. The mean rank for mean-adjusted calling rates during darkness was significantly higher than all other time periods; no other time periods had significantly different mean ranks from one another (darkness mean rank $=218.4$; dawn, morning, afternoon, and dusk $=138.7,153.8,157.3$, and 156.0, respectively; Tukey-Kramer multiple comparison test).

\section{DisCUSSION}

Long-term acoustic recordings from 2000 to 2006 provide a record of right whale presence on the southeast Bering Sea shelf from late May through October or November, and in one year as late as December (Fig. 4). The detection of right whale calls as early as May is consistent with recent and historic sighting data, although a few sightings of right whales in the Bering Sea have been reported as early as April (Scarff 1991, Brownell et al. 2001). The presence of right whales in the SEBS in November and December has not been previously reported, and this finding underscores the usefulness of acoustic monitoring during times of year when visual search effort is typically not conducted. Similarly, year-round acoustic monitoring in the western North Atlantic has recently documented the presence of right whales (E. glacialis) there in late December (Mellinger et al. 2007).

Right whale calls were detected at a northwestern middle-shelf site, BSM-4, on several days in October through December 2005, and at a SEBS slope site, MM4, on one day in June 2005. These sites are outside the currently designated critical habitat boundary for right whales in the Bering Sea (Fig. 1) and may represent important portions of their habitat that warrant further acoustic monitoring and visual search 


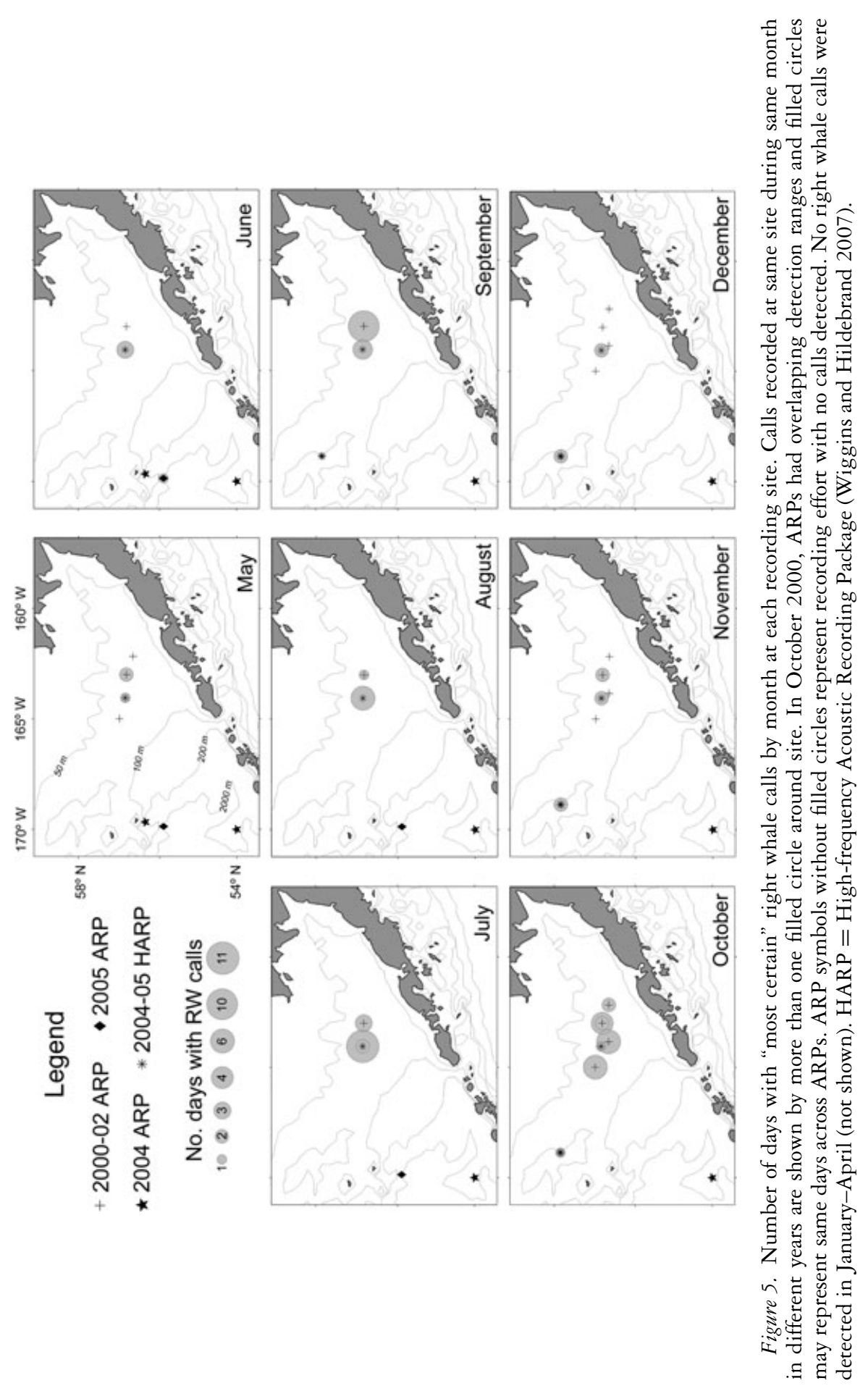




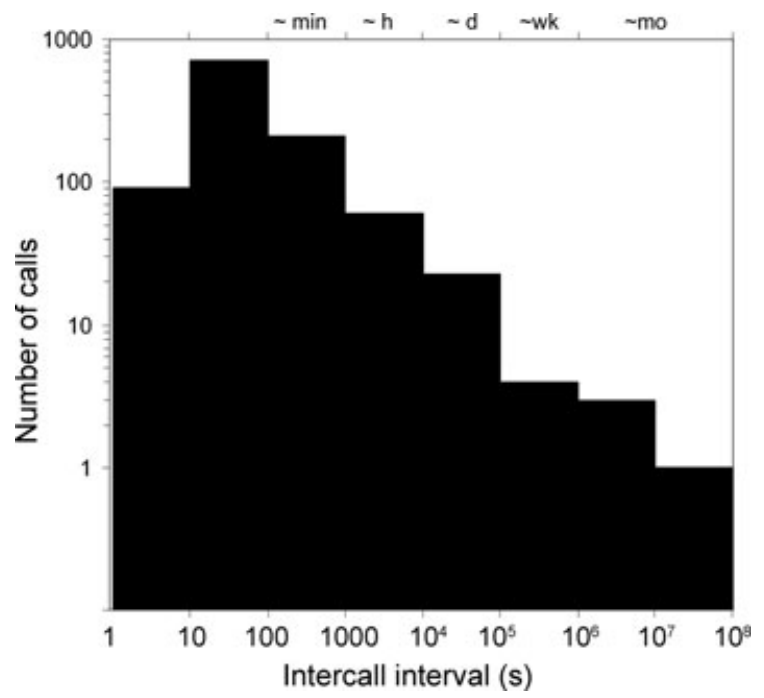

Figure 6. Histogram count of intercall intervals, in seconds, between "most certain" calls ( $n=1,116$ calls) from site C, 31 August 2001-28 July 2002. Both axes are on logarithmic scales. Approximate scales of minutes, hours, days, weeks, and months are shown across top of plot.

effort. Although we did not detect any right whale calls in 5 mo of recording in 2003 near Kodiak Island, right whales have been visually and acoustically detected there during other efforts (Waite et al. 2003, Mellinger et al. 2004b, L. Munger, unpublished data) and right whale research effort should also be continued in this region.

The low numbers or lack of right whale call detections on some recorders may be related to differences in acoustic detection range. When range $(R)$ to a sound source is many times greater than water depth, acoustic propagation approaches a cylindrical spreading model and transmission loss $(T L)$ in decibels is close to $10 \cdot \log R$, whereas for ranges less than the water depth, sound spreads spherically and $T L \approx 20 \cdot \log$ $R$ (Clay and Medwin 1977). Because the SEBS shelf is relatively flat and shallow for hundreds of kilometers, it provides an acoustic waveguide that channels right whale calls and other low-frequency sounds for long distances (Wiggins et al. 2004). Right whale calls are more likely to be detected on the shallow SEBS shelf than at deeper locations with sloping bathymetry such as the Bering slope and Kodiak sites (Fig. 1), where transmission loss due to spherical spreading is greater. Detection ranges of 30-93 km have been reported for right whale calls on the SEBS shelf (McDonald and Moore 2002, Wiggins et al. 2004, Wade et al. 2006), whereas maximum detection ranges of $10-30 \mathrm{~km}$ are reported for low-frequency baleen whale calls in deeper $(>100 \mathrm{~m})$ water (excluding locations in the deep sound channel) and/or in regions with sloping bathymetry (Cummings and Holliday 1985, McDonald et al. 1995, McDonald and Fox 1999, Laurinolli et al. 2003, Greene et al. 2004).

The low overall numbers of right whale calls detected on the SEBS middle shelf and episodic occurrence of days with calls in this study may reflect the low population size for eastern North Pacific right whales. We detected only hundreds of North Pacific 


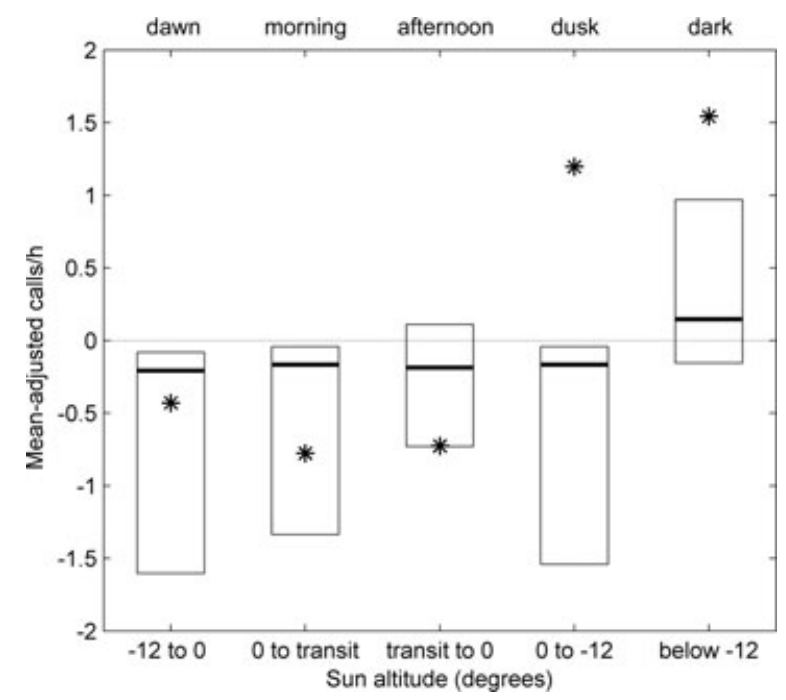

Figure 7. Boxplot of mean-adjusted calls/hour during dawn, morning, afternoon, dusk ( $n=$ $68)$, and dark periods $(n=51)$. Lower and upper bounds of boxes represent lower and upper quartiles, respectively; bold lines are median values and asterisks are mean values. Outliers, not shown, ranged from -15 to 26 (dawn), -15 to 10 (morning), -19 to 5 (afternoon), -15 to 58 (dusk), and -3 to 23 (dark). Note that means (asterisks) in dusk and dark periods are skewed above upper quartile due to high outlier values.

right whale calls in each year of this study, whereas tens to hundreds of thousands of calls were detected in a single migration season(s) for bowhead whales in the western Arctic (Clark et al. 1996), blue and fin whales in the Antarctic (Širović et al. 2004), and blue whales offshore California (Wiggins et al. 2005, Oleson et al. 2007). These latter populations of bowhead, blue and fin whales number in the thousands, compared to the probable population size of fewer than 100 eastern North Pacific right whales.

The highest right whale daily calling rates were on SEBS middle-shelf ARPs during August, September, and December, and may be due to an increase in the total number of calling whales within range or an increase in an individual's calling rate, or both. In a 1999 study, North Atlantic right whale sound production rates were positively correlated with aggregation size, with single whales producing $0-10$ calls $/ \mathrm{h}, 2-10$ whales producing up to $\sim 60 \mathrm{calls} / \mathrm{h}$, and $>10$ whales producing up to 700 calls/h (Matthews et al. 2001). If this is true of North Pacific right whales, our analysis suggests that fewer whales are present in the study area at any time early in the season, compared with larger aggregations in late summer and fall, when they presumably begin migrating off the SEBS shelf. Work is underway to determine call source distances from the ARPs and investigate the relationship of calling rates to the relative number of right whales present.

Calling rates are also likely to be related to behavior, group composition, and other factors. Our call counts are based primarily on upswept (including "down-up") calls, which account for $>80 \%$ of North Pacific right whale calls (McDonald and Moore 2002) and are the most common call type across right whale species (Clark 1982, 1983; Parks and Clark 2007). These calls are thought to function as contact 
calls in southern right whales (Eubalaena australis) (Clark 1982, 1983) and North Atlantic right whales (Parks and Clark 2007), based on their production by all demographic groups (males, females, adults, calves) when approaching or departing from one another. Other call types, such as "gunshot," "down," "constant," "high," or "pulsive" calls, or blows and slaps (Clark 1982, Parks et al. 2005), were associated with relatively more complex social interactions such as mating displays or aggression in southern and North Atlantic right whales, and the relationship between calling rates and behavior, group size, composition, and activity level was correspondingly more complex as well (Clark 1983, Matthews et al. 2001, Parks and Tyack 2005). Our study analyzed only upswept calls and it is not clear what the behavioral function of these calls or other undetected call types may have been.

Right whale calling on the SEBS shelf ARPs is episodic, suggesting that they are traveling in and out of detection range or may be silent for days to weeks. Silent intervals between days with calls ranged from 2 to $49 \mathrm{~d}$ during continuous recording over the right whale "season" and up to 6 mo between the last call detected in fall and the first call detected the following spring. In previous studies when right whales were known to be within acoustic detection range, silent intervals between right whale calling bouts were up to several hours in duration (McDonald and Moore 2002, L. Munger, unpublished data); thus we presume that longer silences, on the order of days, indicate that right whales were not present within detection range. In 2004 a satellite-monitored, tagged North Pacific right whale traveled broadly for hundreds of kilometers over the middle and outer shelf in $40 \mathrm{~d}$, with instances of roughly unidirectional travel for $\sim 100 \mathrm{~km}$ or greater (Wade et al. 2006). Such travel patterns would be sufficient to bring a calling right whale in and out of detection range of middle-shelf hydrophones, especially if the whale is on the periphery of the hydrophone's detection range, i.e., several tens of $\mathrm{km}$ from the deployment site (Wiggins et al. 2004). Therefore, we cannot determine from acoustic recordings whether right whales traveled to other areas of the shelf or off the shelf entirely. In May through July, right whale calls were detected on up to three consecutive days at most, suggesting that the whales travel occasionally through the SEBS middle-shelf study area during late spring/early summer but do not remain there for long periods. The greatest numbers of days with right whales were in July through October, and longest consecutive number of right whale calling days (3-5 d) were in SeptemberOctober, suggesting that right whales travel through most frequently and remain in this area longer in late summer and early fall.

Although our ARPs monitored different periods from year to year, some interannual and spatial variation in right whale occurrence in the SEBS is evident. Right whale calls were detected several weeks earlier in the SEBS in 2002 and 2004 than in 2005, and several weeks later in 2005 than in any previous recording year. Additionally, there seemed to be along-shelf differences in right whale occurrence in late November-December 2005, when calling rates near BSM-4 were high compared to BSM-2. This temporal and spatial variation in right whale call occurrence may indicate a response to variable foraging conditions, both between and within years and across foraging habitats. Unfortunately, there were several gaps in our acoustic monitoring effort that coincided with times when right whales were likely to occur in the SEBS (e.g., most of summer 2001, fall 2002, and summer 2005 at BSM-4), making it difficult to draw conclusions about interannual variability. For instance, a cetacean survey in the SEBS in September 2004 encountered the largest right whale aggregation seen in half a century (Wade et al. 2006) and extremely high calling rates were detected using sonobuoys (L. Munger and S. Rankin, unpublished data); these 
right whale calls were missed by ARPs due to a gap in recording effort during that month. Year-round acoustic monitoring should be continued along the SEBS shelf as well as conducted in other potential right whale habitats to evaluate interannual and spatial variation and long-term trends in right whale occurrence.

Right whale calls detected over nearly one year of continuous monitoring were clustered over several temporal scales (Fig. 6). Ninety percent of calls were detected within tens of seconds to minutes of each other, and most of these "bouts" occurred within approximately one day of each other, with intervals between days with calls ranging from $2 \mathrm{~d}$ to several months. This result is consistent with previous reports for North Pacific right whales (McDonald and Moore 2002, Mellinger et al. 2004b), North Atlantic right whales (Matthews et al. 2001, Vanderlaan et al. 2003, Mellinger et al. 2007), and southern right whales (Payne and Payne 1971). The clustering of calls relates to the probability of detection, such that once a single call is detected, there is a high likelihood of finding additional calls in the hours preceding or following (Munger et al. 2005). However, the period between call clusters even when whales are in the vicinity may be several hours to days, which poses a challenge for real-time acoustic detection of right whales during vessel surveys.

Right whale calling rates showed a minimum during daylight hours and a maximum during dark nighttime hours (Fig. 7), suggesting that individual whales call more frequently at night, or that more individuals call at night. Either possibility implies a diel cycle to right whale acoustic behavior in the SEBS. Calling rates in North Atlantic and southern right whales increased at night in some studies (Clark 1983, Matthews et al. 2001) and decreased in others (Mellinger et al. 2007), and diel calling patterns have been reported for other baleen whale species as well (Au et al. 2000, Stafford et al. 2005, Wiggins et al. 2005). One potential explanation for diel patterns in whale calling is that whales are less likely to produce calls while foraging and therefore calling rates are inversely related to foraging intensity. The increase in night-time calling by right whales on the SEBS shelf may be related to feeding on vertically migrating copepods, their primary prey, during the day when prey are concentrated at depth (e.g., Baumgartner et al. 2003). At some sites in the North Atlantic, right whale calling rates were higher during the day, perhaps indicating nighttime feeding near the surface (Mellinger et al. 2007). Alternatively, right whale calling rates may be related to behavioral displays or interaction that includes visual cues, and higher calling rates at night may be a reallocation of display effort when visual cues are ineffective.

\section{Conclusions}

Long-term acoustic monitoring of North Pacific right whale calls demonstrates that right whales occur intermittently on the SEBS middle shelf from May through December and appear to pass through the study area most frequently and remain for longer durations in July-October. We also provide evidence that right whales are at least occasionally present over the Bering Sea slope, where they were historically abundant (Scarff 1991, Clapham et al. 2004, Shelden et al. 2005). During silences of days to weeks between right whale calling episodes, we hypothesize that right whales travel throughout the southeast Bering Sea, including regions of the middle and outer shelf outside of the detection range of our recorders, and potentially over the SEBS slope, where a relatively smaller area was monitored due to greater acoustic transmission loss. Higher right whale calling rates (calls/day) on the SEBS middle shelf in mid- to late summer (and December 2005) may indicate larger right whale 
aggregation sizes, and higher nightly calling rates suggest a diel component to right whale behavior, perhaps related to foraging or social context.

Further research (e.g., simultaneous acoustic monitoring and visual observation) is needed in order to understand the behavioral context of North Pacific right whale calls and potentially quantify the relationship of calling types/rates to abundance and habitat use. In addition, work relating acoustic recordings to oceanographic data may be useful in understanding and predicting right whale habitat, and could suggest locations for future acoustic monitoring. Continued research effort using a variety of techniques (e.g., acoustic monitoring and visual search effort, satellite telemetry, photographic and genetic identification) should be conducted in areas of recent right whale occurrence as well as in historically important regions to explore for right whale presence. Results are pertinent to management decisions, such as critical habitat designation, that rely on an understanding of the spatial and temporal distribution of North Pacific right whales.

\section{ACKNOWLEDGMENTS}

This work was supported by NOAA Alaska Fisheries Science Center/National Marine Mammal Laboratory (AFSC/NMML) via JIMO budget no. NA17RJ1231, North Pacific Marine Research Institute (project T-2100) and North Pacific Research Board (projects R-0307 and F0519), Alaska Department of Fish and Game (ADFG project T-1-6-4; special thanks to Bob Small), and National Fish and Wildlife Foundation. We thank Phyllis Stabeno and her colleagues from NOAA Pacific Marine Environmental Laboratory for their collaboration in integrating whale acoustic recorders into their moorings and sharing ship time. NOAA Southwest Fisheries Science Center and AFSC/NMML provided opportunities for L. Munger to record right whales during cetacean surveys in Alaska; we thank the cruise leaders Jay Barlow, Rick LeDuc, Lisa Ballance, Robert Pitman, and Paul Wade, acousticians Allan Sauter, Kate Stafford, and Shannon Rankin, and others who were involved in planning and conducting these surveys. Thanks also to the officers and crew of the NOAA research vessels McArthur, McArthur II, and Miller Freeman; the University of Hawaii R/V Kilo Moana, and the fishing vessels Aleutian Mariner and Alaskan Enterprise. Mark McDonald shared data and feedback at the beginning of analysis. Jay Barlow, David Checkley, and Melissa Soldevilla provided helpful comments on this manuscript. This is NPRB publication no.166.

\section{Literature Cited}

Au, W. W. L., J. Mobley, W. C. Burgess, M. O. Lammers and P. E. Nachtigall. 2000. Seasonal and diurnal trends of chorusing humpback whales wintering in waters off western Maui. Marine Mammal Science 16:530-544.

BARLOW, J. 2005. Cruise report: Marine mammal cruise number 1625: Structure of populations, levels of abundance and status of humpbacks (SPLASH), cruise number: AR04-05. March 25, 2005. Southwest Fisheries Science Center (SWFSC) sponsored by U.S. Department of Commerce, NOAA, NMFS, SWFSC Protected Resources Division (PRD). SWFSC, 8604 La Jolla Shores Drive, La Jolla, CA 92038.

Baumgartner, M. F., T. V. N. Cole, R. G. Campbell, G. J. Teegarden and E. G. Durbin. 2003. Associations between North Atlantic right whales and their prey, Calanus finmarchicus, over diel and tidal time scales. Marine Ecology Progress Series 264:155-166.

Brownell, R. L. JR., P. J. Clapham, T. Miyashita and T. Kasuya. 2001. Conservation status of North Pacific right whales. Journal of Cetacean Research and Management (Special Issue) 2:269-286.

Cerchio, S., J. K. Jacobsen and T. F. Norris. 2001. Temporal and geographical variation in songs of humpback whales, Megaptera novaeangliae: Synchronous 
change in Hawaiian and Mexican breeding assemblages. Animal Behavior 62:313329.

Clapham, P. J., C. Good, S. E. Quinn, R. R. Reeves, J. E. Scarff and R. L. Brownell, JR. 2004. Distribution of North Pacific right whales (Eubalaena japonica) as shown by 19th and 20th century whaling catch and sighting records. Journal of Cetacean Research and Management 6:1-6.

Clark, C. W. 1982. The acoustic repertoire of the southern right whale, a quantitative analysis. Animal Behavior 30:1060-1071.

Clark, C. W. 1983. Acoustic communication and behavior of the southern right whale (Eubalaena australis). Pages 163-198 in R. Payne, ed. Communication and behavior of whales. Westview Press, Boulder, CO.

Clark, C. W., AND P. J. Clapham. 2004. Acoustic monitoring on a humpback whale (Megaptera novaeangliae) feeding ground shows continual singing into late spring. Proceedings of the Royal Society of London series B 271:1051-1057.

Clark, C. W., R. Charif, S. Mitchell and J. Colby. 1996. Distribution and behavior of the bowhead whale, Balaena mysticetus, based on analysis of acoustic data collected during the 1993 spring migration off Point Barrow, Alaska. Report of the International Whaling Commission 46:541-552.

Clay, C. S., And H. Medwin. 1977. Acoustical oceanography: Principles and applications. John Wiley \& Sons, New York, NY.

Cummings, W. C., AND D. V. HollidAy. 1985. Passive acoustic location of bowhead whales in a population census off Point-Barrow, Alaska. Journal of the Acoustical Society of America 78:1163-1169.

Doroshenko, N. V. 2000. Soviet whaling for blue, gray, bowhead and right whales in the North Pacific Ocean, 1961-1979. Pages 96-103 in A. V. Yablokov and V. A. Zemsky, eds. Soviet whaling data (1949-1979). Center for Russian Environmental Policy, Moscow, Russia.

Federal Register. 6 July 2006. Rules and Regulations Department of Commerce National Oceanic and Atmospheric Administration 50 CFR Part 226 [Docket No. 0510182716157-02; I.D. 101405C] RIN 0648-AT84 Endangered and Threatened Species; Revision of Critical Habitat for the Northern Right Whale in the Pacific Ocean AGENCY: National Marine Fisheries Service, National Oceanic and Atmospheric Administration, Commerce. ACTION: Final Rule. 71(129):38277-38297.

Fristrup, K. M., L. T. HATCh AND C. W. Clark. 2003. Variation in humpback whale (Megaptera novaeangliae) song length in relation to low-frequency sound broadcasts. Journal of the Acoustical Society of America 113:3411-3424.

GiLLESPIE, D. 2004. Detection and classification of right whale calls using an 'edge' detector operating on a smoothed spectrogram. Canadian Acoustics 32:39-47.

GODDARD, P. D., AND D. J. RUGH. 1998. A group of right whales seen in the Bering Sea in July 1996. Marine Mammal Science 14:344-349.

Greene, C. R., M. W. Mclennan, R. G. Norman, T. L. McDonald, R. S. Jakubczak AND W. J. RICHARDSON. 2004. Directional frequency and recording (DIFAR) sensors in seafloor recorders to locate calling bowhead whales during their fall migration. Journal of the Acoustical Society of America 116:799-813.

IEEE. 1979. Programs for digital signal processing. Chapter 8. IEEE Press, Piscataway, NJ.

Laurinolli, M. H., A. E. Hay, F. Desharnais and C. T. Taggart. 2003. Localization of North Atlantic Right whale sounds in the bay of fundy using a sonobuoy array. Marine Mammal Science 19:708-723.

LeDuc, R. G. 2004. Report of the results of the 2002 survey for North Pacific right whales. U.S. Department of Commerce, NOAA Technical Memorandum NMFS-SWFSC-357. Available from Southwest Fisheries Science Center, 8604 La Jolla Shores Drive, La Jolla, California 92038. 58 pp.

LeDuc, R. G., W. L. Perryman, J. W. Gilpatrick, Jr., J. Hyde, C. Stinchcomb, J. V. Carretta AND R. L. Brownell, JR. 2001. A note on recent surveys for right whales 
in the southeastern Bering Sea. Journal of Cetacean Research and Management (Special Issue) 2:287-289.

Matthews, J. N. 2004. Detection of frequency-modulated calls using a chirp model. Canadian Acoustics 32:66-75.

Matthews, J. N., S. Brown, D. Gillespie, M. Johnson, R. Mclanaghan, A. Moscrop, D. NowACEK, R. LEAPER, T. LEWIS AND P. TyACK. 2001. Vocalisation rates of the North Atlantic right whale (Eubalaena glacialis). Journal of Cetacean Research and Management 3:271-282.

Mattila, D. K., L. N. Guinee And C. A. Mayo. 1987. Humpback whale songs on a North Atlantic feeding ground. Journal of Mammalogy 684:880—883.

McDonald, M. A., AND C. G. Fox. 1999. Passive acoustic methods applied to fin whale population density estimation. Journal of the Acoustical Society of America 105:26432651.

McDonald, M. A., AND S. E. Moore. 2002. Calls recorded from North Pacific right whales (Eubalaena japonica) in the eastern Bering Sea. Journal of Cetacean Research and Management 4:261-266.

McDonald, M. A., J. A. Hildebrand and S. C. WebB. 1995. Blue and fin whales observed on a sea-floor array in the northeast Pacific. Journal of the Acoustical Society of America 98:712-721.

McSweeney, D. J., K. C. Chu, W. F. Dolphin And L. N. Guinee. 1989. North Pacific humpback whale songs: A comparison of southeast Alaskan feeding ground songs with Hawaiian wintering ground songs. Marine Mammal Science 5:139148.

Mellinger, D. K. 2001. Ishmael 1.0 User's Guide. NOAA Technical Report OARPMEL-120, Seattle, WA. 26 pp. Available from http://cetus.pmel.noaa.gov/cgibin/MobySoft.pl.

Mellinger, D. K., K. M. Stafford And C. G. Fox. 2004a. Seasonal occurrence of sperm whale (Physeter macrocephalus) sounds in the Gulf of Alaska, 1999-2001. Marine Mammal Science 20:48-62.

Mellinger, D. K., K. M. Stafford, S. E. Moore, L. Munger and C. G. Fox. $2004 b$. Detection of north Pacific right whale (Eubalaena japonica) calls in the Gulf of Alaska. Marine Mammal Science 20:872-879.

Mellinger D. K., S. L. Nieukirk, H. Matsumoto, S. L. Heimlich, R. P. Dziak, J. Haxel, M. Fowler, C. Meinig AND H. V. Miller. 2007. Seasonal occurrence of North Atlantic right whale (Eubalaena glacialis) vocalizations at two sites on the Scotian Shelf. Marine Mammal Science 23:856-867.

Moore, S. E., J. M. Waite, L. L. Mazzuca And R. C. Hobbs. 2000. Mysticete whale abundance and observations of prey associations on the central Bering Sea shelf. Journal of Cetacean Research and Management 2:227-234.

Moore, S. E., K. M. Stafford, D. K. Mellinger and J. A. Hildebrand. 2006. Listening for large whales in the offshore waters of Alaska. BioScience 56:49-55.

Munger, L. M., D. K. Mellinger, S. M. Wiggins, S. E. Moore and J. A. Hildebrand. 2005. Performance of spectrogram cross-correlation in detecting right whale calls in long-term recordings from the Bering Sea. Canadian Acoustics 33:25-34.

Oleson, E. M., S. M. Wiggins And J. A. Hildebrand. 2007. Temporal separation of blue whale call types on a southern California feeding ground. Animal Behaviour 74:881894.

Parks, S. E., AND C. W. Clark. 2007. Acoustic communication: Social sounds and the potential impacts of noise. Pages 3103-3132 in S. D. Kraus and R. M. Rolland, eds. The urban whale: North Atlantic right whales at the crossroads. Harvard University Press, Cambridge, MA.

Parks, S. E., AND P. L. TyACK. 2005. Sound production by North Atlantic right whales (Eubalaena glacialis) in surface active groups. Journal of the Acoustical Society of America 117:3297-3306. 
Parks, S. E., P. K. Hamilton, S. D. Kraus and P. L. Tyack. 2005. The gunshot sound produced by male North Atlantic right whales (Eubalaena glacialis) and its potential function in reproductive advertisement. Marine Mammal Science 21:458475 .

PAYNe, R. S., AND S. MCVAY. 1971. Songs of humpback whales. Science 173:585-597.

PAYNE R., AND K. PAYNE. 1971. Underwater sounds of southern right whales. Zoologica 56:159-165.

SCARFF, J. E. 1991. Historic distribution and abundance of the right whale (Eubalaena glacialis) in the North Pacific, Bering Sea, Sea of Okhotsk and Sea of Japan from the Maury whale charts. Report of the International Whaling Commission 41:467-489.

SCARFF, J. E. 2001. Preliminary estimates of whaling-induced mortality in the 19th century North Pacific right whale (Eubalaena japonicus) fishery, adjusting for struck-but-lost whales and non-American whaling. Journal of Cetacean Research and Management (Special Issue) 2:261-268.

Shelden, K. E. W., S. E. Moore, J. M. Waite, P. R. Wade and D. J. Rugh. 2005. Historic and current habitat use by North Pacific right whales, Eubalaena japonica, in the Bering Sea and Gulf of Alaska. Mammal Review 35:129-155.

Širović, A., J. A. Hildebrand, S. M. Wiggins, M. A. McDonald, S. E. Moore And D. THIELE. 2004. Seasonality of blue and fin whale calls and the influence of sea ice in the Western Antarctic Peninsula. Deep-Sea Research II 51:2327-2344.

SMITH, W. H. F., AND D. T. SANDWELL. 1997. Global seafloor topography from satellite altimetry and ship depth soundings. Science 277:1956-1962.

StAfFord, K. M., S. L. Nieukirk AND C. G. Fox. 2001. Geographic and seasonal variation of blue whale calls in the North Pacific. Journal of Cetacean Research and Management 3:65-76.

Stafford, K. M., S. E. MoOre And C. G. Fox. 2005. Diel variation in blue whale calls recorded in the eastern tropical Pacific. Animal Behavior 69:951-958.

Thompson, P. O., AND W. A. Friedl. 1982. A long term study of low frequency sounds from several species of whales off Oahu, Hawaii. Cetology 45:1-19.

Thompson P. O., L. T. Findley AND O. VidAl. 1992. 20-Hz pulses and other vocalizations of fin whales, Balaenoptera physalus, in the Gulf of California, Mexico. Journal of the Acoustical Society of America 92:3051-3057.

Townsend, C. H. 1935. The distribution of certain whales as shown by logbook records of American whaleships. Zoologica (NY) 19:1-50 + 6 maps.

Tynan, C. T., D. P. DeMaster And W. T. Peterson. 2001. Endangered right whales on the southeastern Bering Sea shelf. Science 294:1894.

VanderlaAn, A. S. M., A. E. Hay And C. T. TAggart. 2003. Characterization of North Atlantic right whale (Eubalaena glacialis) sounds in the Bay of Fundy. IEEE Journal of Oceanic Engineering 28:164-173.

Wade, P., M. P. Heide-Jorgensen, K. Shelden, J. Barlow, J. Carretta, J. Durban, R. LeDuc, L. Munger, S. Rankin, A. Sauter and C. Stinchcomb. 2006. Acoustic detection and satellite-tracking leads to discovery of rare concentration of endangered North Pacific right whales. Biology Letters 2:417-419.

Waite, J. M., K. Wynne And D. K. Mellinger. 2003. Documented sighting of a North Pacific right whale in the Gulf of Alaska and post-sighting acoustic monitoring. Northwestern Naturalist 84:38-43.

Watkins W. A., P. Tyack, K. E. MoOre And J. E. BiRD. 1987. The 20-Hz signals of finback whales (Balaenoptera physalus). Journal of the Acoustical Society of America 82:19011912.

WIgGINS, S. 2003. Autonomous Acoustic recording packages (ARPs) for long-term monitoring of whale sounds. Marine Technical Science Journal 37:13-22.

Wiggins, S. M., AND J. A. Hildebrand. 2007. High-frequency acoustic recording package (HARP) for broad-band, long-term marine mammal monitoring. International Symposium on Underwater Technology 2007 and International Workshop on Scientific Use of 
Submarine Cables \& Related Technologies, 17-20 April 2007 Tokyo, Japan, Institute of Electrical and Electronics Engineers. pp. 551-557.

Wiggins, S. M., M. A. McDonald, L. M. Munger, J. A. Hildebrand and S. E. Moore. 2004. Waveguide propagation allows range estimates for North Pacific right whales in the Bering Sea. Canadian Acoustics 32:146-154.

Wiggins, S. M., E. M. Oleson, M. A. McDonald and J. A. Hildebrand. 2005. Blue whale (Balaenoptera musculus) diel call patterns offshore of southern California. Aquatic Mammals 31:161-168.

Zar, J. H. 1999. Biostatistical analysis. Prentice Hall, Upper Saddle River, NJ.

Received: 2 August 2007

Accepted: 21 March 2008 